\title{
EVALUATION OF EQUILIBRIUM STATE OF CHINA REAL ESTATE MARKET BASED ON AHP
}

\author{
Li Xin-xin \\ Department of Civil Engineering, Shandong Jiao Tong University, Jinan, Shandong Province, China \\ Email: Ixx1995@126.com
}

Keywords: The Real Estate Market, Balanced, AHP, Real estate policy

Abstract. Real estate industry is the foundational, guiding and pillar industry of the national economy, and they are closely linked, therefore, guiding and promoting real estate industry in a sustained, stable and healthy development is beneficial to both the people and nation. That will not only meet the basic housing needs of people, but also maintain the steady and rapid economic growth of the national economy, and also promote the construction of our country economy and social development goal. China's real estate policies in recent years are analyzed in this paper. And build China's real estate market equilibrium development index system by AHP. Then evaluate the development of the real estate market situation in our country in recent years by using the index system, so as to promote our country real estate market balanced development.

\section{Introduction}

The real estate is the most basic and most important means of production of the national economy, and is indispensable material conditions and space of the social activities. There's a lot of abnormal development status in the real estate, such as the demand of real estate market is relatively large, the housing supply structure is irrational. Whether the real estate market is balanced developed and how to ensure the balanced development is one of the people most concerned problems. Some reasonable strategies to promote China's real estate market healthy development can be produced based on the analysis of the development of the real estate market.

\section{Market equilibrium and real estate market equilibrium}

Market equilibrium is that the buyers and sellers exchange equally with price to achieve balance of supply and demand in perfect market condition in order to realize the market equilibrium price. At the same time, supply and demand sides can be realized gross balance and don't exist in excess demand and excess supply ${ }^{[1]}$. Market equilibrium is the precondition of market system and price system. When the market system is not perfect or market main body is mature, the price adjustment can not only realize the balance of demand and supply in the market, namely the non equilibrium state. China's real estate market is in the non equilibrium condition. The analysis of China's real estate market development should firstly analysis the characteristics of China's real estate market.

\section{The characteristics of China's real estate market}

The real estate market has the general market characteristics, such as by the law of value and rule of supply and demand constraint ${ }^{[2]}$, also has some distinction at other product market characteristics because of the different characteristics of the real estate commodity and other goods.

1) Natural supply lacks flexibility. Because land which is a scarce resource and lack of flexibility is one of the most important elements of the real estate market, the overall supply of real estate market is certain and the real estate price depends on the demand of real estate goods.

2) Supply with lag. The supply of the real estate commodity can be affected by adjusting the related land policy according to the real estate market development situation. But the real estate commodity supply has lagged behind because the real estate commodity has characteristics of long cycle, large investment, irreversible production. 
3) Demand has diversity and hierarchy. Different consumers of real estate commodity have different preferences on price, location, environment quality and purchasing purpose. At the same time, the real estate commodity has value and value-added characteristics.

4) Substitution of spatial is poor. Real estate is property collectively of houses and land ${ }^{[2]}$, which is position fixed, when the real estate market supply and demand of a region isn't equilibrium, it is difficult to exchange from other areas which other commodities can do this.

5) Non equilibrium. The two sides of market transactions have asymmetric information because the real estate market is technical, regional and irreplaceable, not sufficient market competition, imperfect market system. Thus the market price will not fully reflect the market supply and demand; the price system is not perfect.

6) Policy effected. The real estate market is high added value, great influence on other industry of national economy, involving people's economic benefits. The real estate market has a monopoly and periodic fluctuation. Market alone cannot achieve good control effect because of information asymmetry of the real estate market. Thus the government's macroeconomic policy in the real estate market is very important.

\section{AHP}

AHP is a simple, flexible and practical multiple criteria decision making method for the qualitative problem undertakes quantitative analysis. It can make a complex problem be well-organized by dividing various factors into orderly level units which contact with each other. Because the influent factors of the real estate market is numerous, it is a very complicated to study its development. But AHP has a larger advantage in dealing with this kind of problem. Therefore, this paper will use AHP to evaluate the development of the real estate market.

\section{The evaluation of real estate market equilibrium state}

To ensure the accuracy of evaluation results must ensure the rationality of the index system. Availability and operability must be considered in the setting of index. Index system should be simple, feasible and should also have certain prediction ability so as to suggest the future development of the real estate market.

Market equilibrium must reflect fairness and efficiency. The efficiency of real estate market is mainly reflected in: the equilibrium of supply and demand, no excess supply and excess demand, high efficient utilization of all related resources such as land, funds, quality improvement of the real estate commodity. Fairness is embodied in: reasonable housing structure, perfect housing safeguard system, small gap of the level of housing. In view of this, according to AHP, this paper establishes three administrative levels of the hierarchy model (the target layer, criterion, and index layer) (Fig. 1 and Tab. 1).

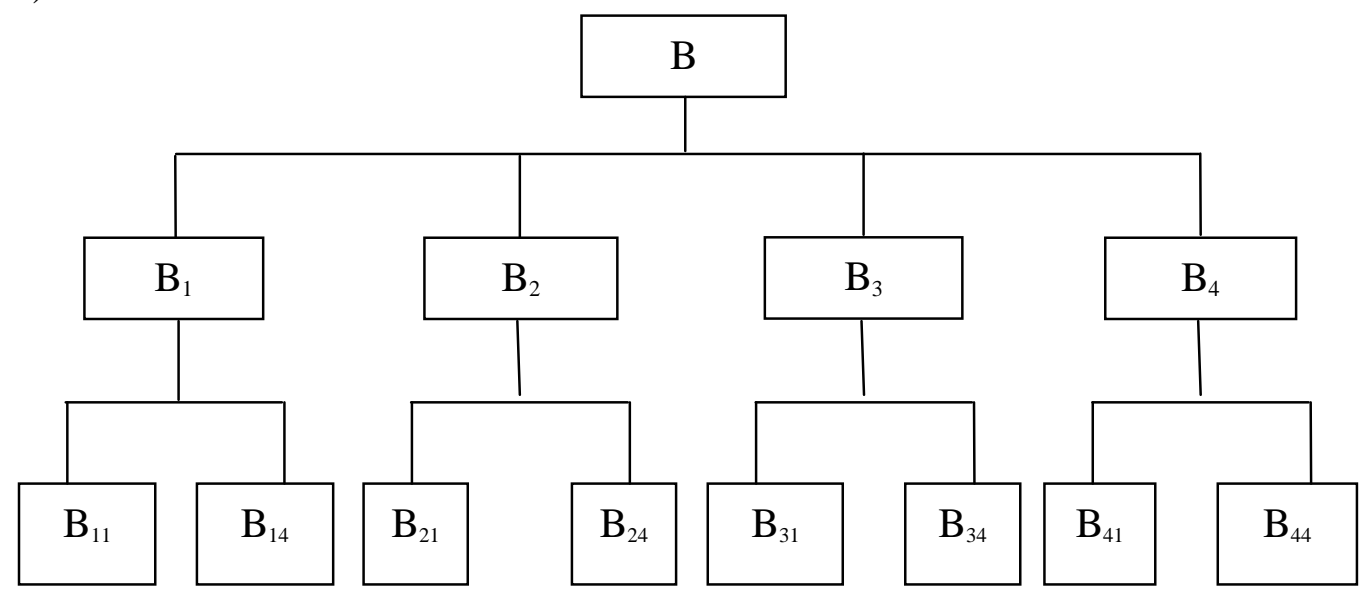

Fig. 1 the balanced hierarchy structure of Real estate market development index system 
Considering each index can be obtained and index properties, quantitative indicators are used as far as possible. The indicators of each level are all set four level two indexes according to the research results ${ }^{[3-5]}$ of some scholars. The real estate market balanced development index system is shown in table1.

\begin{tabular}{|c|c|c|}
\hline $\begin{array}{l}\text { General } \\
\text { objective }\end{array}$ & Criterion layers & Index layers \\
\hline \multirow{4}{*}{$\begin{array}{l}\text { Real estate } \\
\text { market } \\
\text { equilibrium } \\
\text { development } \\
\text { B }\end{array}$} & $\begin{array}{l}\text { Market supply } \\
\mathrm{B}_{1}\end{array}$ & $\begin{array}{l}\text { Land utilization rate }\left(\mathrm{B}_{11}\right) \\
\text { The growth of real estate investment /The growth of } \\
\mathrm{GDP}\left(\mathrm{B}_{12}\right) \\
\text { Real estate investment /Total investment in fixed assets }\left(\mathrm{B}_{13}\right) \\
\text { Average number of employees }\left(\mathrm{B}_{14}\right)\end{array}$ \\
\hline & $\begin{array}{l}\text { Market demand } \\
\qquad \mathrm{B}_{2}\end{array}$ & $\begin{array}{l}\text { Housing price to income ratio }\left(\mathrm{B}_{21}\right) \\
\text { Housing mortgage / Residents income }\left(\mathrm{B}_{22}\right) \\
\text { Residential consumption expenditure }\left(\mathrm{B}_{23}\right) \\
\text { City residential construction area per capita }\left(\mathrm{B}_{24}\right)\end{array}$ \\
\hline & $\begin{array}{c}\text { Transactions } \\
\mathrm{B}_{3}\end{array}$ & $\begin{array}{l}\text { Trading area }\left(B_{31}\right) \\
\text { The price of real estate }\left(B_{32}\right) \\
\text { Rate to sale ratio }\left(B_{33}\right) \\
\text { Vacancy rate }\left(B_{34}\right)\end{array}$ \\
\hline & $\begin{array}{l}\text { The attention of } \\
\text { the government } \\
\mathrm{B}_{4}\end{array}$ & $\begin{array}{l}\text { The proportion of property tax in revenue }\left(\mathrm{B}_{41}\right) \\
\text { Real estate loan ratio }\left(\mathrm{B}_{42}\right) \\
\text { Affordable housing construction scale }\left(\mathrm{B}_{43}\right) \\
\text { Government supervision }\left(\mathrm{B}_{44}\right)\end{array}$ \\
\hline
\end{tabular}

Tab.1 index system of Real estate market equilibrium

The weight of the indexes should be firstly determined in order to analyze the development of the real estate market. This paper adopts questionnaire to determine the weight of each index. We distributed 30questionnaires, recycled 28(25 effective questionnaires among them). The comparison judgment matrix can be attained based on the survey of questionnaires. The index matrixes are shown in table2.

\begin{tabular}{c|cccc}
\hline$B-B_{i}$ & $B_{1}$ & $B_{2}$ & $B_{3}$ & $\mathbf{B}_{4}$ \\
\hline $\mathrm{B}_{1}$ & 1 & $1 / 2$ & $1 / 3$ & $1 / 3$ \\
$\mathrm{~B}_{2}$ & 2 & 1 & $1 / 2$ & $1 / 2$ \\
$\mathrm{~B}_{3}$ & 3 & 2 & 1 & 1 \\
\hline $\mathbf{B}_{4}$ & 3 & 2 & 1 & 1 \\
\hline
\end{tabular}

\begin{tabular}{c|cccc}
\hline$B_{1}-B_{1 i}$ & $B_{11}$ & $B_{12}$ & $B_{13}$ & $\mathbf{B}_{\mathbf{1 4}}$ \\
\hline $\mathrm{B}_{11}$ & 1 & 3 & 5 & 7 \\
$\mathrm{~B}_{12}$ & $1 / 3$ & 1 & 2 & 5 \\
$\mathrm{~B}_{13}$ & $1 / 5$ & $1 / 2$ & 1 & 3 \\
\hline $\mathbf{B}_{\mathbf{1 4}}$ & $1 / 7$ & $1 / 5$ & $1 / 3$ & 1 \\
\hline
\end{tabular}




\begin{tabular}{c|cccc}
\hline$B_{2}-B_{2 i}$ & $B_{21}$ & $B_{22}$ & $B_{23}$ & $\mathbf{B}_{24}$ \\
\hline $\mathrm{B}_{21}$ & 1 & 5 & 3 & 4 \\
$\mathrm{~B}_{22}$ & $1 / 5$ & 1 & $1 / 3$ & $1 / 2$ \\
$\mathrm{~B}_{23}$ & $1 / 3$ & 3 & 1 & 2 \\
\hline $\mathbf{B}_{24}$ & $1 / 4$ & 2 & $1 / 2$ & 1 \\
\hline
\end{tabular}

\begin{tabular}{c|cccc}
\hline$B_{3}-B_{3 i}$ & $B_{31}$ & $B_{32}$ & $B_{33}$ & $\mathbf{B}_{\mathbf{3 4}}$ \\
\hline $\mathrm{B}_{31}$ & 1 & $1 / 5$ & $1 / 2$ & $1 / 7$ \\
$\mathrm{~B}_{32}$ & 5 & 1 & 3 & $1 / 2$ \\
$\mathrm{~B}_{33}$ & 2 & $1 / 3$ & 1 & $1 / 5$ \\
\hline $\mathbf{B}_{\mathbf{3 4}}$ & 7 & 2 & 5 & 1 \\
\hline
\end{tabular}

\begin{tabular}{c|cccc}
\hline$B_{4-}-B_{4 i}$ & $B_{41}$ & $B_{42}$ & $B_{43}$ & $\mathbf{B}_{44}$ \\
\hline $\mathrm{B}_{41}$ & 1 & $1 / 3$ & $1 / 5$ & $1 / 7$ \\
$\mathrm{~B}_{42}$ & 3 & 1 & $1 / 3$ & $1 / 5$ \\
$\mathrm{~B}_{43}$ & 5 & 3 & 1 & $1 / 2$ \\
\hline $\mathbf{B}_{44}$ & 7 & 5 & 2 & 1 \\
\hline
\end{tabular}

\section{Tab.2 Judgment matrix}

Each index should be consistency tested for the accuracy of weight. According to the judgment matrix, indexes were ranked and consistency checked by using Matlab software. The ranking vector of the matrix or the criterion layer are $\mathrm{W}=[0.1091,0.1891,0.3509,0.3509], \mathrm{W}_{1}=[0.5738$,

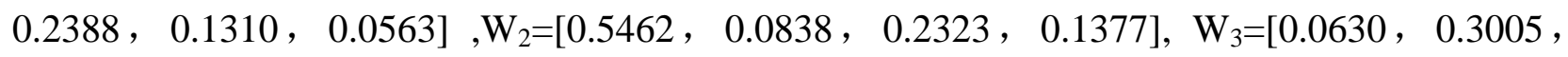
$0.1098,0.5267], \mathrm{W}_{4}=[0.0570,0.1222,0.2976,0.5232]$. By conformance test, $\mathrm{CR}=0.0038<0.1, \quad \mathrm{CR}_{1}=0.0288<0.1, \quad \mathrm{CR}_{2}=0.0189<0.1, \mathrm{CR}_{4}=0.0254<0.1$, the hierarchical ranking result are all satisfactory consistency. Thus, Index layer on the weight of the total goal sorted as follows:

$$
\mathrm{W}^{\prime}=\left[\begin{array}{cccc}
0.5738 & 0 & 0 & 0 \\
0.2388 & 0 & 0 & 0 \\
0.1310 & 0 & 0 & 0 \\
0.0563 & 0 & 0 & 0 \\
0 & 0.5462 & 0 & 0 \\
0 & 0.0838 & 0 & 0 \\
0 & 0.2323 & 0 & 0 \\
0 & 0.1377 & 0 & 0 \\
0 & 0 & 0.0630 & 0 \\
0 & 0 & 0.3005 & 0 \\
0 & 0 & 0.1098 & 0 \\
0 & 0 & 0.5267 & 0 \\
0 & 0 & 0 & 0.0570 \\
0 & 0 & 0 & 0.1222 \\
0 & 0 & 0 & 0.2976 \\
0 & 0 & 0 & 0.5232
\end{array}\right] \times\left[\begin{array}{l}
0.1091 \\
0.1891 \\
0.3509 \\
0.3509
\end{array}\right]=\left[\begin{array}{l}
0.0626 \\
0.0261 \\
0.0143 \\
0.0061 \\
0.1033 \\
0.0158 \\
0.0439 \\
0.0260 \\
0.0221 \\
0.1054 \\
0.0385 \\
0.1848 \\
0.0200 \\
0.0429 \\
0.1044 \\
0.1836
\end{array}\right]
$$

By consistency inspection of the hierarchy ordering, $\mathrm{CR}=0.0203<0.1$, therefore, the consistency test of total sequencing passed. 
In a word, every index has passed the test of consistency, namely, they are of great credibility, but the index in the established index system is both qualitative and quantitative, furthermore, measurement unit and reflected contents differ from index to index. To define the development of real estate market, the value of each index has to be set, and index itself has to be revised. Through investigation, these indexes can be roughly divided into income type, cost type and interval type, for income type, the bigger the value is, the better, for cost type, the value is opposite to that of income type, for interval type, the nearer the value to interval, the better. The data of each index is processed by dimensionless method, and the value is between $[0-1]^{[6]}$ to achieve the goal of uniform unit across the indexes. As for index of income type, the higher the value is, the better, which can be done with formula (1):

$$
\mathrm{b}_{\mathrm{ij}}^{\prime}=\frac{b_{i j}-\min \left(b_{i j}\right)}{\max \left(b_{i j}\right)-\min \left(b_{i j}\right)}
$$

here, $\min \left(b_{\mathrm{ij}}\right)$ and $\max \left(\mathrm{b}_{\mathrm{ij}}\right)$ are minimal value and maximal value among the index values respectively. The lower the value, the better, this can be done with formula (2):

$$
\mathrm{b}_{\mathrm{ij}}^{\prime}=\frac{\max \left(b_{i j}\right)-b_{i j}}{\max \left(b_{i j}\right)-\min \left(b_{i j}\right)}
$$

For the index of interval type, the near the value to the interval[c, d], the better, and it can be done with formula (3):

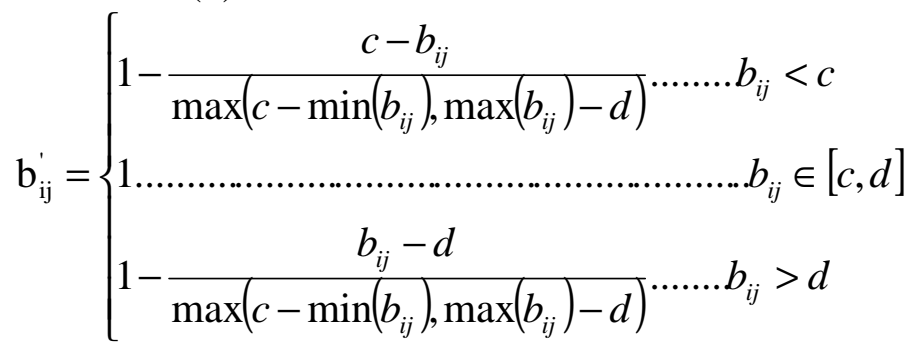

\section{Foundation project:}

1. Doctoral Fund Project of Shandong Jiao Tong University: Research on land resource allocation based on the balanced development of the real estate market

\section{References}

[1]Wu Qing. The Study on the Balanced and Corresponded Development of Real Estate Market Based on Stakeholders--A Case Study of Qingdao[D].TongJi University, 2008:72-77

[2]Fang Mei. Real Estate Market and Coordinated Development of Urban Economy[D]. HuaZhong University of Science and Technology, 2006:70-80

[3]Cui Xinming. Factors and Empirical Studies of Urban Housing Prices[M]. Beijing: Economic Science Press, 2005:20-26

[4]Wan Lunlai, Chen Xixi. The Effect of FDI on Technical Efficiency of Real Estate Market-- The Empirical Study Of Panel Data Based on Interprovincial Real Estate Market of China[J].

Shanghai Journal of Economics, 2007(3):66-71.

[5]Sun Ge. The Operational Efficiency Study of China Real Estate Industry Based Upon DEA[J].

Economic Research Guide, 2007(9):174-176.

[6]Li Bainian. Fuzzy Mathematics and its Application[M]. Hefei: Hefei University of Technology

Publishing House, 2007:84-92 